\title{
How to Teach the Basic Concept of Function in Senior High School: a Lesson Study
}

\author{
Yalei Shao ${ }^{1}$, Ying Zhou ${ }^{1, a)}$, Tommy Tanu Wijaya ${ }^{1}$, Lijuan Gan $^{1}$ \\ ${ }^{1}$ Guangxi Normal University \\ 1 Yanzhong Road, Yanshan, Guilin, Guangxi, China, 541006 \\ a)zhouying66@mailbox.gxnu.edu.cn
}

\begin{abstract}
Teaching methods are a complex topic in mathematics education. This study aims to analyze the teaching methods of previous relevant studies and design a new lesson study on how to teach the topic of functions at the high school level in China. Lesson study focuses on the basic concepts of function and problemsolving abilities. The researcher uses the research and development method to teach the material function at the high school level. This Lesson Study is used to teach in China. The researcher explains 4 important aspects in designing a lesson study, namely the introduction or opening section, the instructional section or core section, the assessment section, and the closing section.
\end{abstract}

Keywords: Function; Lesson Study; Senior High School; Teaching Methods

\begin{abstract}
Abstrak. Metode pembelajaran adalah topik yang kompleks dalam pendidikan matematika. Penelitian ini bertujuan untuk menganalisis metode pengajaran pada penelitian sebelumnya yang relevan dan merancang lesson study baru tentang bagaimana mengajar topik fungsi di tingkat Sekolah Menengah Atas (SMA) di Tiongkok. Lesson study berfokus pada konsep dasar fungsi dan kemampuan pemecahan masalah. Peneliti menggunakan metode research and devel-opment untuk mengajarkan materi fungsi di tingkat SMA. Lesson Study ini digunakan untuk mengajar di Tiongkok. Peneliti menjelaskan 4 aspek penting dalam merancang lesson study yaitu bagian pendahuluan atau bagian pem-bukaan, bagian instruksional atau bagian inti, bagian penilaian, dan bagian penutup.
\end{abstract}

Kata kunci: Lesson Study; Materi Fungsi; Metode Pembelajaran; Sekolah Menengah AtasCovid-19 


\section{INTRODUCTION}

At this time there are still problems with mathematics education (Arifah \& Retnawati, 2020; Lapitan, Tiangco, Sumalinog, Sabarillo, \& Diaz, 2021; Ngirishi \& Bansilal, 2019; Sister, Syahputra, \& Sinaga, 2020). research shows that there are 3 problems in mathematics education, which students still have difficulty filling in story questions (Haryanti, Herman, \& Prabawanto, 2019; Soifer, 2017; Stigler, J. W., Fuson, K. C., Ham \& Kim, 1986), there is no innovation in teaching methods (Khine, Ali, \& Afari, 2017; Zulnaidi, Oktavika, \& Hidayat, 2020) and There is no feeling involved when teaching (Baya'a \& Daher, 2013; Kang, 2015). The current standard curriculum is no longer suitable for using traditional methods of teaching mathematics. Teachers must have good Pedagogical Knowledge to combine mathematics textbooks and how to teach in class (Graziano, Herring, Carpenter, Smaldino, \& Finsness, 2017; Wijaya \& Hermita, 2021). This Research considered that mathematical concepts were better incorporated into the daily lives of students (Sarwinda, Rohaeti, \& Fatharani, 2020; Van den Heuvel-Panhuizen \& Drijvers, 2014; Yang, Tseng, \& Wang, 2017). So that students can get deep learning while studying mathematics.

The researcher also analyzed the difficulties in several countries regarding learning mathematics and found that mathematics is still considered difficult and a subject that students do not like-pedagogical and low technological knowledge (Ding \& Zhao, 2020; Hahn, 2020; Khodaie, Moghadamzadeh, \& Salehi, 2011; Kulsum, Hidayat, Wijaya, \& Kumala, 2019).

The researcher concludes that the current way of teaching mathematics must be changed and modified for the better. Good teaching methods go both ways between the teacher and students, not just the teacher who explains the material. From this background, researchers in China continue to develop new effective and efficient teaching methods to help students get high math scores and master mathematical concepts by using technology (Tan, Zou, Wijaya, Suci, \& Dewi, 2020; Wijaya, 2021; Wijaya, Ying, \& Purnama, 2020; Zhang, Zhou, \& Wijaya, 2020). The researcher focuses on the development of lesson study as an example of improving teacher pedagogical knowledge. Lesson study focuses on the mastery of basic concepts, problem-solving abilities, and student interest in learning.

Functions are a topic in chapter 1 on the mathematics textbook of the master publisher. According to The Mathematics Curriculum Standards for General High School (2017 edition), the objectives of learning functions are: First learn to describe what functions and variables are, the relationship between functions, the basic concepts of functions, changing the form of a story into a function graph, understanding each element of the function. The second is to master the relationship between the topics of function in everyday life (in pictures, graphs of functions, and analysis methods), how to use the concept of functions in everyday life. 
Many studies show the difficulties of teachers and students when explaining the function material (Cunhua, Ying, Qunzhuang, \& Wijaya, 2019; Ng \& Sinclair, 2018; Wijaya, Ying, Chotimah, et al., 2020). Lin Chongde (Zhu Wenfang, 2000) conducted a study on 802 students from grade 10 to grade 12 in 6 schools in Beijing and found no difference in students' ability in the concept of function. Li Jibao (Li, 2003) analyzed why the concept of function matter was difficult to understand and found 2 reasons: the basic concept of function material was not clearly explained. The second reason is that students find it difficult to change the story problem and change mathematics. Wang Xiaoqin (Ren \& Wang, 2007) gave test questions to students to determine the mathematical understanding ability of junior high and high school students on the function material. He uses statistical analysis for data processing. Research shows that each student has a different understanding of the basic concepts of function. In the research of Wang Xiaoqin, it can be concluded that the basic concepts of material functions in mathematical textbooks are not easy to understand and remember. Students often only remember formulas and do not understand the true concept of math material.

From some of the studies above, the researcher saw that the concept of function material was complicated for students to master, so teaching and learning activities were not appropriate if they used a simple traditional approach and students only listened passively. The teacher must direct students to discover the concept of the function for themselves to get deep learning. These research purposes are making lesson studies that focus on the basic concept of mathematics and efficient teaching methods; to improve teacher pedagogical knowledge when teaching mathematics; facilitating students to understand mathematical concepts easily; and improving students' mathematical understanding skills.

\section{METHOD}

The making of a lesson study was carried out in December 2020-May 2021 in class 10 mathematics lessons. The math topics in this study are functions. Lesson study development is carried out at Guangxi Normal University. This type of research is classroom action research (CAR) using a qualitative descriptive approach (Dewi, Wijaya, Budianti, \& Rohaeti, 2018; Suweken, 2018). The research path can be seen in Figure 1.

First, researchers discuss with supervisors to determine which math topics are difficult. Second, researchers looked for data on student difficulties and then compiled lesson plans to help teachers explain these math topics. Finally, the researchers gave the lesson plans to supervisors and material experts for non-formal validation. This research only reached the validation stage. The implementation stage of the lesson plan will be continued in the following research. 


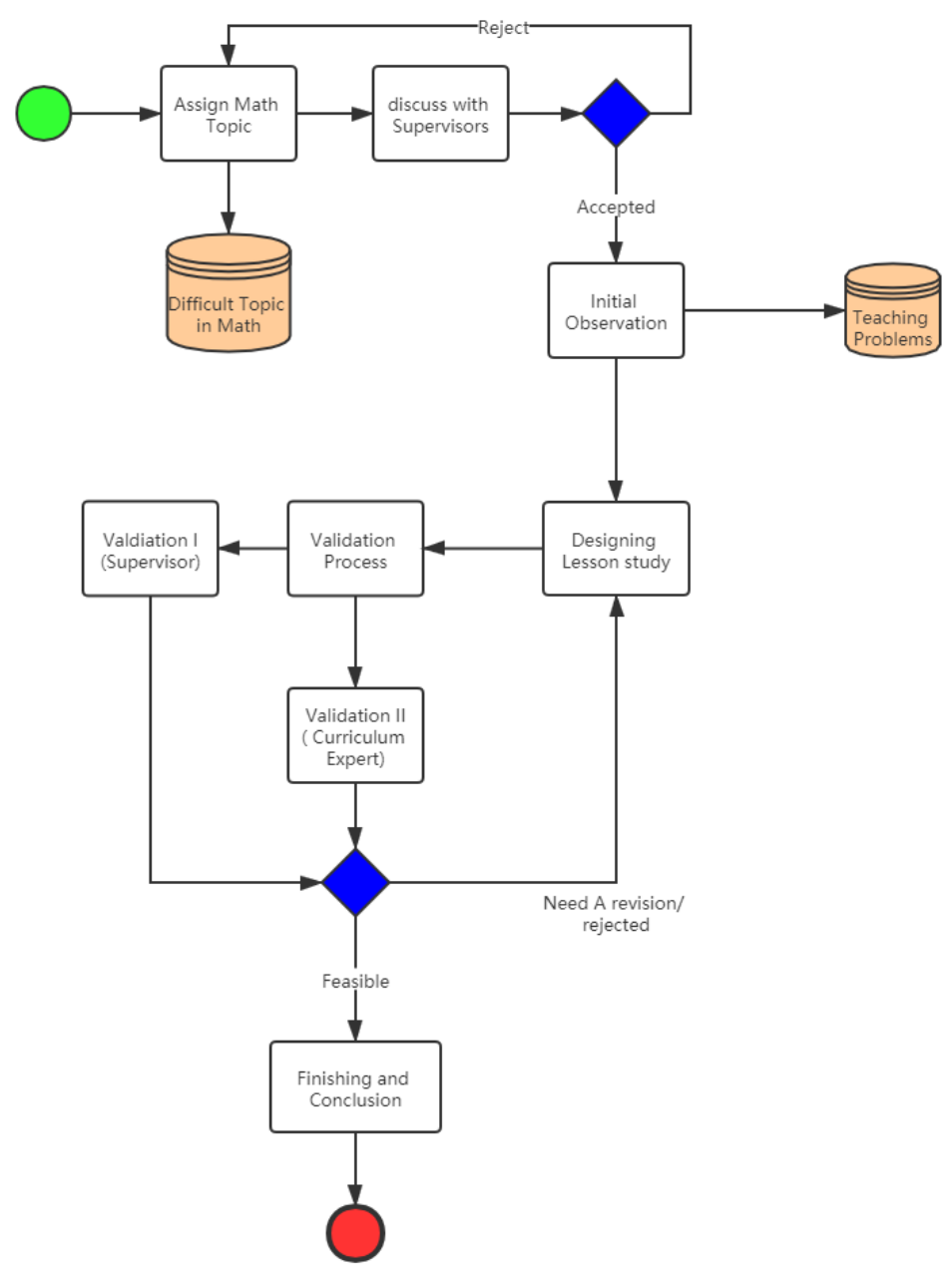

Figure 1. Research Plans for Making Lesson Study on the Function Material

\section{RESULTS AND DISCUSSION}

\section{Introduction Section}

The teacher determines the conditions of teaching and learning at the time of the opening lesson. The opening lesson is very important and has a big influence on students' interest in learning. Subotnik R.'s research (Subotnik, Miserandino, \& Olszewski-Kubilius, 1996) said that opening will affect the course of teaching and learning activities and affect students' activeness in the classroom. the teacher must lead inspiration and higher-order thinking from students (Ilmi, Sukarmin, \& Sunarno, 2020; Ilmi et al., 2020). directing students to get the basic concepts of function material. The opening of the function material can be linked to daily activities. The lesson plans in the Introduction Part can be seen in Table 1. 
Tabel 1. Opening Question on Lesson Plan

No. Example of Opening Question
1. The following figure shows the 2007 baseline and 2010 tracking data of the survey of fertility intention and
fertility behavior in Jiangsu Province. Look at the two curves and answer:
Are they functions? Why is that?
Please use a set to represent the range of variation of these two variables (age, percentage), and think about
how the elements in these two sets correspond.

2. A cuboid swimming pool is to be built in a place with a water depth of 1.8 meters. Describe the function between the side length and the volume of the swimming pool, and use the set and corresponding language to describe the function.

3. The table below shows the temperature of a place from 8:00 to 20:00 a day. Answer:

(1) Is temperature a function of time? Can you write an analytical expression for this function?

(2) 12:00 and 18:00 at the same temperature, why is it still a function?

(3) Suppose the temperature suddenly drops to 0 at 20:00. Is it still a function?

\begin{tabular}{|c|c|c|c|c|c|c|c|}
\hline Moment & $8: 00$ & $10: 00$ & $12: 00$ & $14: 00$ & $16: 00$ & $18: 00$ & $20: 00$ \\
\hline Temperature & $9^{\circ} \mathrm{C}$ & $11^{\circ} \mathrm{C}$ & $12^{\circ} \mathrm{C}$ & $10^{\circ} \mathrm{C}$ & $13^{\circ} \mathrm{C}$ & $12^{\circ} \mathrm{C}$ & $8^{\circ} \mathrm{C}$ \\
\hline
\end{tabular}

In Table 1, the researcher gives three questions to the opening section using a realistic approach or dealing with daily life problems. Questions are not easy to answer and can provoke students' high-order thinking skills.

In question number 1, researchers can increase students' interest in learning. The first is by provoking students to think simply and inviting them to think that this problem is taken from real situations. In question number 2 , the teacher can ask what students know from the question and direct them to look for the concept of the function. Let students look for functional relationships to solve everyday problems. When students express opinions and discuss, students' mathematical abilities will increase. In question number 3, let students work on the problem themselves and find their answers. This question will improve students' mathematical abstraction skills.

From the opening section, it can be concluded that mathematics lessons should be studentcentered. This research is supported by previous research (Akbulut, Dindar, Kucuk, \& Sesen, 2020). practice questions must be related to everyday life. This statement is following previous research. A realistic approach will improve students' mathematical abilities (Alim, Fauzan, Arwana, \& Musdi, 2020; Putri \& Zulkardi, 2018). 


\section{Instructional Process}

In the Instructional Process section, the teacher can direct students to define the concept of function. The use of learning technology can increase students' interest in learning and changing the classroom atmosphere (Hsu, 2015; Khine et al., 2017; Lin, Huang, \& Chang, 2019; Newhouse, 2017). Technology also enhances the student experience (Akbulut et al., 2020; Maeng, Mulvey, Smetana, \& Bell, 2013; Suweken, 2018; Voithofer, Nelson, Han, \& Caines, 2019; Yang et al., 2017). Much mathematical software can be used to define the concept of function (S. Chotimah, Wijaya, Aprianti, Akbar, \& Bernard, 2020; Wijaya, Ying, \& Suan, 2020; Zhang et al., 2020). The teacher can direct students on how to use technology to get the concept of function. De porter's research (Siti Chotimah, Bernard, \& Wulandari, 2018; Wijaya, Jianlan, \& Purnama, 2020) said it is better for students to only hear and see when students do their research.

Table 2. Essential Attributes and Non-Essential Attributes of Function Concepts

\begin{tabular}{cccc}
\hline & Attribute & Value (1) & Value (2) \\
\cline { 2 - 4 } $\begin{array}{c}\text { Essential } \\
\text { attributes }\end{array}$ & arbitrariness & $\forall x \in A$ & $\exists x \notin A$ \\
\hline \multirow{2}{*}{$\begin{array}{c}\text { uniqueness } \\
\text { attributes }\end{array}$} & $\begin{array}{c}\text { so } f(x) \text { of } x \text { is unique } \\
\text { for } x, f(x) \in B\end{array}$ & the $f(x)$ corresponding to $x$ is not \\
unique, $f(x) \in B$
\end{tabular}

Based on Table 2, the researcher asked the students, "what are real numbers?". After that, after students have mastered what real numbers are, students can learn the basic symbols in the function material.

In the next step, the teacher can use mathematical software to explain the element function, the definition of the domain, and the relationship between the 2 functions. Students will not feel sleepy and bored if students use technology to explain functions.

\section{Assessment Section}

Providing practice questions to students can be used as evaluation material to determine whether students have mastered the basic concepts of functions. Problem practice is an important part of the teaching and learning process. Research shows that practice questions can improve students' mathematical understanding abilities.

Examples of questions for which the function is given must be various (Cai, Ding, \& Wang, 2014; Howson, 1995). There are many forms for practice questions, namely, visual, audio, and combined. Giving questions must be examined the level of difficulty of the questions. The questions given should not be too easy and not too difficult. Problems that are too easy will not 
improve students' mathematical abilities. And questions that are too difficult will make students less interested in learning and students will think mathematics is a difficult and boring subject. Examples of questions on the function material can be seen in Table 3.

Table 3. Examples of Practice Questions in the Assessment Section

No. Practice

1. Example 1: In the following figure, the function is represented by ( ).

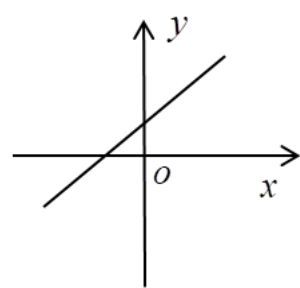

(1)

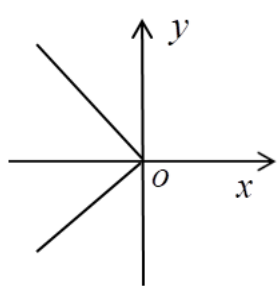

(2)

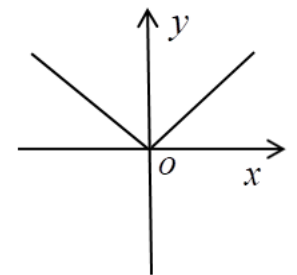

(3)

2. Example 2: Use function images to determine if they are functions?
(1) $y=1$;
(2) $x=1$

3. Example 3: Determine whether the following two functions are the same?

(1) $f(x)=2 x,(2) f(x)=\frac{2 x^{2}}{x}$

\section{Closing Section}

The closing section is where students conclude what they have learned during the opening section, instructional process, and problem practice. Reflection is an important part of the teaching and learning process that can improve students' critical thinking skills.

At this stage, the researcher allows students to conclude the basic concepts of function, function use, function elements, and function relationships in everyday life. The researcher gave several questions to direct students to conclude the basic concepts of the function material (Table 4).

Table 4. Questions on the Closing Section

\begin{tabular}{cl}
\hline No. & \multicolumn{1}{c}{ Question } \\
\hline 1. & How do we determine the relationship between functions between 2 variables? \\
\hline 2. & How do we prove that two functions are the same? \\
\hline 3. & What is the difference of $y$ and $f(x)$ in a function? \\
\hline 4. & Can we use other symbols to replace $f(x)$ function symbols? \\
\hline 5. & Can the domain and the range of a function be an empty set? Must be a set of numbers? \\
\hline
\end{tabular}

The questions in Table 4 correspond to the lessons that students have learned in the previous stages. When students review and draw conclusions, students will form new knowledge, analytical 
skills, and problem-solving. in the end, students will remember all the basic concepts. When students find knowledge in their way, it is not easy to forget the knowledge.

\section{CONCLUSION}

Teaching mathematics should focus on basic concepts. Students will not find it difficult to do practice questions and final exams to understand the basic concept. Only when students analyze and find the concept of function in their way will it improve higher-order thinking skills. The teacher's role is to direct students to find the concept of function, linking the concept of function to students' daily lives.

This paper only explains the making of lesson plans about function material. Meanwhile, there is still much material at the high school level that students find very difficult. Future research can make lesson plans on other mathematical material. This paper also only develops lesson plans and has not been implemented in class. Implementation in class to improve students' mathematical abilities and soft skills will be carried out described in other papers.

\section{ACKNOWLEDGMENT}

Research on the consistency between the mathematics test and the curriculum standard of the college entrance examination under the core literacy perspective (Innovation Project of Guangxi Graduate Education 2021, NO.YCSW2021102).

\section{REFERENCES}

Akbulut, C., Dindar, A. ., Kucuk, S., \& Sesen, B. . (2020). Development and Validation of the ICT-TPACKScience Scale. Journal of Science Education and Technology, 29, 185-218. https://doi.org/10.15818/ihss.2016.17.3.185

Alim, J. A., Fauzan, A., Arwana, I. M., \& Musdi, E. (2020). Model of Geometry Realistic Learning Development with Interactive Multimedia Assistance in Elementary School. Journal of Physics: Conference Series, 1471(1). https://doi.org/10.1088/1742-6596/1471/1/012053

Arifah, A. N., \& Retnawati, H. (2020). Are students having trouble solving problems polyhedron? Journal of Physics: Conference Series, 1613(1). https://doi.org/10.1088/1742-6596/1613/1/012029

Baya'a, N., \& Daher, W. (2013). Mathematics teachers' readiness to integrate ICT in the classroom. International Journal of Emerging Technologies in Learning, 8(1), 46-52. https://doi.org/10.3991/ijet.v8i1.2386

Cai, J., Ding, M., \& Wang, T. (2014). How do exemplary Chinese and U.S. mathematics teachers view instructional coherence? Educational Studies in Mathematics, 85(2), 265-280. https://doi.org/10.1007/s10649-013-9513-3

Chotimah, S., Wijaya, T. T., Aprianti, E., Akbar, P., \& Bernard, M. (2020). Increasing primary school students ' reasoning ability on the topic of plane geometry by using hawgent dynamic mathematics software. Journal of Physics: Conference Series, 1657(1), 012009. https://doi.org/10.1088/1742$\underline{6596 / 1657 / 1 / 012009}$

Chotimah, Siti, Bernard, M., \& Wulandari, S. M. (2018). Contextual approach using VBA learning media to improve students' mathematical displacement and disposition ability. Journal of Physics: Conference Series, 948(1). https://doi.org/10.1088/1742-6596/948/1/012025 
Cunhua, L., Ying, Z., Qunzhuang, O., \& Wijaya, T. T. (2019). Mathematics course design based on six questions cognitive theory using hawgent dynamic mathematic. Journal On Education, 02(01), 36-44.

Dewi, S. N., Wijaya, T. T., Budianti, A., \& Rohaeti, E. E. (2018). Pengaruh Model Teams Games Tournament Terhadap Kemampuan Pemahaman Matematik Siswa Kelas XI SMK di Kota Cimahi Pada Materi Fungsi Eksponen. WACANA AKADEMIKA: Majalah Ilmiah Kependidikan, 2(1), 99. https://doi.org/10.30738/wa.v2i1.2570

Ding, Y., \& Zhao, T. (2020). Emotions, engagement, and self-perceived achievement in a small private online course. Journal of Computer Assisted Learning, 36(4), 449-457. https://doi.org/10.1111/jcal.12410

Graziano, K. J., Herring, M. C., Carpenter, J. P., Smaldino, S., \& Finsness, E. S. (2017). A TPACK Diagnostic Tool for Teacher Education Leaders. TechTrends, 61(4), 372-379. https://doi.org/10.1007/s11528-017-0171-7

Hahn, A. J. (2020). Basic calculus of planetary orbits and interplanetary flight: The missions of the Voyagers, Cassini, and Juno. In Basic Calculus of Planetary Orbits and Interplanetary Flight: The Missions of the Voyagers, Cassini, and Juno. https://doi.org/10.1007/978-3-030-24868-0

Haryanti, M. D., Herman, T., \& Prabawanto, S. (2019). Analysis of students' error in solving mathematical word problems in geometry. Journal of Physics: Conference Series, 1157(4). https://doi.org/10.1088/1742-6596/1157/4/042084

Howson, G. (1995). Mathematics textbooks: A comparative study of grade 8 texts. Pacific Educational Press, 3.

Hsu, Y. S. (2015). Development of science teachers' TPACK: East Asian practices. Development Of Science Teachers' TPACK: East Asian Practices, 1-153. https://doi.org/10.1007/978-981-287-441-2

Ilmi, A. M., Sukarmin, \& Sunarno, W. (2020). Development of TPACK based-physics learning media to improve HOTS and scientific attitude. Journal of Physics: Conference Series, 1440(1). https://doi.org/10.1088/1742-6596/1440/1/012049

Kang, W. (2015). Selected Regular Lectures from the 12th International Congress on Mathematical Education. Selected Regular Lectures from the 12th International Congress on Mathematical Education, (1), 405-416. https://doi.org/10.1007/978-3-319-17187-6

Khine, M. S., Ali, N., \& Afari, E. (2017). Exploring relationships among TPACK constructs and ICT achievement among trainee teachers. Education and Information Technologies, 22(4), 1605-1621. https://doi.org/10.1007/s10639-016-9507-8

Khodaie, E., Moghadamzadeh, A., \& Salehi, K. (2011). Factors affecting the probability of academic cheating school students in Tehran. Procedia - Social and Behavioral Sciences, 29, 1587-1595. https://doi.org/10.1016/j.sbspro.2011.11.401

Kulsum, S. I., Hidayat, W., Wijaya, T. T., \& Kumala, J. (2019). Analysis on high school students' mathematical creative thinking skills on the topic of sets. Jurnal Cendekia: Jurnal Pendidikan Matematika, 03(02), 431-436. https://doi.org/https://doi.org/10.31004/cendekia.v3i2

Lapitan, L. D., Tiangco, C. E., Sumalinog, D. A. G., Sabarillo, N. S., \& Diaz, J. M. (2021). An effective blended online teaching and learning strategy during the COVID-19 pandemic. Education for Chemical Engineers, 35(May 2020), 116-131. https://doi.org/10.1016/j.ece.2021.01.012

Li, J. (2003). Some questions about the teaching of function concepts. Journal of Mathematics Education, 02, 95-98 (In Chinese).

Lin, Y. L., Huang, S. W., \& Chang, C. C. (2019). The impacts of a marine science board game on motivation, interest, and achievement in marine science learning. Journal of Baltic Science Education, 18(6), 907-923. https://doi.org/10.33225/jbse/19.18.907

Maeng, J. L., Mulvey, B. K., Smetana, L. K., \& Bell, R. L. (2013). Preservice Teachers' TPACK: Using Technology to Support Inquiry Instruction. Journal of Science Education and Technology, 22(6), 838857. https://doi.org/10.1007/s10956-013-9434-z

Newhouse, C. P. (2017). STEM the Boredom: Engage Students in the Australian Curriculum Using ICT with Problem-Based Learning and Assessment. Journal of Science Education and Technology, 26(1), 44- 


\section{7. https://doi.org/10.1007/s10956-016-9650-4}

Ng, O.-L., \& Sinclair, N. (2018). Drawing in Space: Doing Mathematics with 3D Pens. In Uses of Technology in Primary and Secondary Mathematics Education, ICME-13 Monographs (pp. 301-313). https://doi.org/10.1007/978-3-319-76575-4_16

Ngirishi, H., \& Bansilal, S. (2019). An exploration of high school learners' understanding of geometric concepts. Problems of Education in the 21st Century, 77(1), 82-96. https://doi.org/10.33225/PEC/19.77.82

Putri, R. I. I., \& Zulkardi. (2018). Learning fraction through the context of Asian Games 2018. Journal of Physics: Conference Series, 1088. https://doi.org/10.1088/1742-6596/1088/1/012023

Ren, M., \& Wang, X. (2007). Middle school students' understanding of the concept of function-a preliminary exploration of historical similarity. Journal of Mathematics Education, 04, $84-87$ (In Chinese).

Sarwinda, K., Rohaeti, E., \& Fatharani, M. (2020). The development of audio-visual media with contextual teaching learning approach to improve learning motivation and critical thinking skills. 2(2), 98-114.

Sister, D., Syahputra, E., \& Sinaga, B. (2020). Analysis of students' difficulties in mathematical creative thinking on problem-based learning model. International Journal of Scientific and Technology Research, 9(3), 3842-3845.

Soifer, A. (2017). The Colorado Mathematical Olympiad Is Mathematics; It Is Sport; It Is Art. And It Is Also Community, by Matthew Kahle. In The Colorado Mathematical Olympiad: The Third Decade and Further Explorations: From the Mountains of Colorado to the Peaks of Mathematics (Vol. 1, pp. 1259). https://doi.org/10.1007/978-3-319-52861-8

Stigler, J. W., Fuson, K. C., Ham, M., \& Kim, M. S. (1986). An analysis of addition and subtraction word problems in American and Soviet elementary mathematics textbooks. Cognition and Instruction, 3.

Subotnik, R. F., Miserandino, A. D., \& Olszewski-Kubilius, P. (1996). Implications of the Olympiad studies for the development of mathematical talent in schools. International Journal of Educational Research, 25(6), 563-573. https://doi.org/10.1016/S0883-0355(97)86733-X

Suweken, G. (2018). On the implementation of e-learning with mathlet GeoGebra in Analytic Geometry course to improve students' engagement and achievement. Journal of Physics: Conference Series, 1040(1). https://doi.org/10.1088/1742-6596/1040/1/012034

Tan, S., Zou, L., Wijaya, T. T., Suci, N., \& Dewi, S. (2020). Improving student creative thinking ability with problem based learning approach using hawgent. Journal on Education, 02(04), 303-312.

Van den Heuvel-Panhuizen, M., \& Drijvers, P. (2014). Realistic Mathematics Education. In Encyclopedia of Mathematics Education. https://doi.org/10.1007/978-94-007-4978-8_170

Voithofer, R., Nelson, M. J., Han, G., \& Caines, A. (2019). Factors that influence TPACK adoption by teacher educators in the US. Educational Technology Research and Development, 67(6), 1427-1453. https://doi.org/10.1007/s11423-019-09652-9

Wijaya, T. T. (2021). How Chinese students learn mathematics during the coronavirus pandemic. International Journal of Educational Research and Innovation (IJERI), 15, 1-16. https://doi.org/https://doi.org/10.46661/ijeri.4950

Wijaya, T. T., \& Hermita, N. (2021). What is TPMK? (1st ed.). Bandung, Indonesia: AE publishing.

Wijaya, T. T., Jianlan, T., \& Purnama, A. (2020). Developing an Interactive Mathematical Learning Media Based on the TPACK Framework Using the Hawgent Dynamic Mathematics Software. Emerging Technologies in Computing, 318-328. https://doi.org/10.1007/978-3-030-60036-5

Wijaya, T. T., Ying, Z., Chotimah, S., Bernard, M., Zulfah, \& Astuti. (2020). Hawgent dynamic mathematic software as mathematics learning media for teaching quadratic functions. Journal of Physics: Conference Series, 1592(1). https://doi.org/10.1088/1742-6596/1592/1/012079

Wijaya, T. T., Ying, Z., \& Purnama, A. (2020). Using Hawgent Dynamic Mathematics Software in Teaching Trigonometry. International Journal of Emerging Technologies in Learning, 15(10), 215-222. https://doi.org/10.3991/ijet.v15i10.13099 
Wijaya, T. T., Ying, Z., \& Suan, L. (2020). Using Geogebra in Teaching Plane Vector. Journal of Innovative Mathematics Learning, 3(1), 15-23.

Yang, D. C., Tseng, Y. K., \& Wang, T. L. (2017). A comparison of geometry problems in middle-grade mathematics textbooks from Taiwan, Singapore, Finland, and the United States. Eurasia Journal of Mathematics, Science and Technology Education, 13(7), 2841-2857. https://doi.org/10.12973/eurasia.2017.00721a

Zhang, L., Zhou, Y., \& Wijaya, T. T. (2020). Hawgent dynamic mathematics software to improve problemsolving ability in teaching triangles. Journal of Physics: Conference Series, 1663(1). https://doi.org/10.1088/1742-6596/1663/1/012069

Zhu Wenfang, L. C. (2000). The characteristics of the development of the function concept of junior high school students. Psychological Science, 05.

Zulnaidi, H., Oktavika, E., \& Hidayat, R. (2020). Effect of use of GeoGebra on achievement of high school mathematics students. Education and Information Technologies, 25(1), 51-72. https://doi.org/10.1007/s10639-019-09899-y 